\title{
Developing and validating the Perioperative Thirst Discomfort Scale*
}

\author{
Elaboração e validação de Escala de Desconforto da Sede Perioperatória \\ Elaboración y validación de escala de incomodidad de la sed perioperatoria
}

\author{
Pamela Rafaela Martins ${ }^{1}$, Lígia Fahl Fonseca ${ }^{1}$, Edilaine Giovanini Rossetto ${ }^{1}$, Lilian Denise Mai ${ }^{2}$
}

How to cite this article:

Martins PR, Fonseca LF, Rossetto EG, Mai LD. Developing and validating the Perioperative Thirst Discomfort Scale. Rev Esc Enferm USP. 2017;51:e03240. DOI: http://dx.doi.org/10.1590/S1980-220X2016029003240

* Extracted from the dissertation "Elaboração e validação de uma Escala de Desconforto da Sede Perioperatória”, Programa de PósGraduação em Enfermagem, Universidade Estadual de Londrina, 2016.

${ }^{1}$ Universidade Estadual de Londrina, Londrina, PR, Brazil.

${ }^{2}$ Universidade Estadual de Maringá, Maringá, PR, Brazil.

\begin{abstract}
Objective: Developing and validating a scale to assess perioperative thirst discomfort. Method: A methodological research conducted in 2014 and 2015 at the surgical center of a public hospital in the north of Paraná, Brazil. The scale was developed after literature review, followed by face and content validation, and reliability assessment through its internal consistency and inter-observer equivalence. Results: Seven items make up the scale: dry mouth; dry lips; thick tongue; thick saliva; dry throat, bad taste and desire to drink water. The content validity index for attributes and items was 0.98 , and the reliability index was 1 for the scale attributes and items. Internal consistency assessed by Cronbach's alpha was 0.91 and inter-rater equivalence was 1 , as measured by weighted kappa coefficient. Conclusion: The Perioperative Thirst Discomfort Scale showed high content and reliability indexes.
\end{abstract}

DESCRIPTORS

Thirst; Scales; Evaluation; Perioperative Nursing; Validation Studies. 


\section{INTRODUCTION}

Thirst is described as the desire to drink water, influenced by physiological factors and an individual's life habits $^{(1)}$. When not quenched by water intake, thirst becomes an unpleasant feeling so imperative that it can outweigh all the others ${ }^{(2)}$.

Surgical patients are part of a group at high risk of developing both osmotic and hypovolemic thirst ${ }^{(1,3)}$. In the perioperative period, patients are exposed to several factors predisposing to the thirst symptom, such as prolonged preoperative fasting, anesthetic-surgical medications, orotracheal intubation and blood loss ${ }^{(1-4)}$. When the confluence of these factors are added to anxiety, irritability, stress and fear of anesthesia and surgery ${ }^{(2,4-5)}$,it results in thirst being one of the most distressing aspects for the patient.

Thirst is a subjective experience that exceeds physical boundaries, covering psychological, social, spiritual and environmental dimension of the person ${ }^{(6)}$. Patients' reports on the experience of thirst in the perioperative period describe it as intense suffering, with allusions to thoughts of despair and even death ${ }^{(7)}$. Paradoxically, thirst remains undervalued, undermeasured and undertreated in clinical practice ${ }^{(1,8)}$.

Based on the assumption that care is the main objective of nursing work, the quest for comfort is a goal to be achieved, integrated into a larger dimension in the midst of dynamic processes, experiences and concepts such as quality of life, hope, control, revitalization and balance. Thirst, like any situation of imbalance, triggers changes in the scenario of the patient undergoing surgery, transforming the experience into discomfort along with repercussions on their recovery ${ }^{(9)}$.

Creating a sphere of comfort for the patient thus becomes a complex challenge ${ }^{(6)}$, and the first step to support adopting relief measures is by measuring thirst.

Several mechanisms identify and measure thirst such as brain mapping by tomography and resonance, as well as osmotic and hormonal changes. In the same way, the individual's perception of themselves through visual analog scales (VAS) and numerical verbal scales (NVS) have been extensively employed in pain assessments, with evidence of reliability also for assessing thirst intensity by osmotic changes. There is evidence that the scores obtained by VAS and NVS are positively correlated with high levels of antidiuretic hormone and blood osmolarity ${ }^{(10)}$.

The subjective character of thirst makes it difficult to assess, recognize and measure, especially when it involves patients with impaired communication ${ }^{(1)}$. Among the main symptoms experienced by patients in an intensive care unit (ICU), thirst was the second most intense, uncomfortable and occurring symptom ${ }^{(11)}$.

A Thirst Discomfort Scale was tested with 247 patients on hemodialysis, assessing thirst intensity through a $\operatorname{VAS}^{(12)}$. Also, an 18-item checklist proved to be valid and reliable for measuring thirst in patients with advanced dementia who could not verbalize their desire to drink water ${ }^{(13)}$. A Xerostomia (aka dry mouth) Inventory with 11 items related to the conditions imposed by oral cavity dryness was also validated for its reliability ${ }^{(14)}$.
Nonetheless, existing thirst assessment, measurement, and discomfort scales are destined for critically ill patients or those submitted to hemodialysis who are predisposed to developing thirst or its peripheral symptoms due to the chronicity of their clinical conditions. These instruments consider items that are inappropriate to the surgical patient: they are extensive, assessing constructs that are difficult for the surgical patient to score and they do not discriminate components and dimensions that make up the experience of being thirsty in the perioperative context.

Despite surgical patients presenting intense and highly incident thirst, studies that have developed instruments to measure the characteristics and intensity of this discomfort specifically in this context have not been found, mainly due to its inherent subjectivity ${ }^{(7,15)}$. Thus, it is essential to have a valid and reliable instrument available to assess the magnitude of perioperative thirst discomfort and to propose an adoption of relief measures.

Measurement instruments must be valid and reliable in their application, so that the results have credibility and legitimacy ${ }^{(16)}$. Thus, the purpose of this study was to develop and validate a scale for evaluating perioperative thirst discomfort.

\section{METHOD}

This is a methodological study, ideal for investigating methods to obtain, organize and analyze data that result in validating instruments and research techniques, with a high level of reliability and reproducibility ${ }^{(17)}$.

This study was conducted in 2014 and 2015 in the surgical center of a public hospital in the north of Paraná, accredited to the Unified Health System. It was developed according to the assumptions of Pasquali ${ }^{(18)}$ for developing psychological tools based on the COSMIN checklist (COnsensusbased Standards for the selection of health status Measurement INstruments) $)^{(19)}$, and carried out in three procedures: theoretical; experimental or empirical; and analytical or statistical ${ }^{(18)}$.

The theoretical procedure stage consisted of developing the scale based on the construct "thirst discomfort", with its face and content validation done by specialists.

The construct and its attributes, which comprise a multifactorial of thirst signals were defined after an extensive bibliographical review of the literature, as well the Thirst Study and Research Group (GPS) database of the Universidade Estadual de Londrina.

The most representative attributes were included to compose the scale. Four members of the GPS participated in this analysis along with a professor-researcher unfamiliar with the thirst theme in aiming to assign a neutral look to the attributes' selection.

Next, the constitutive definition was carried out. The thirst discomfort object represented the universe of interest, and the explicitness of properties and attributes represented the defining of that universe. Then we defined the dimensionality of discomfort, conceptualizing both the object and its attributes in detail, taking into account relevant literature, experts in the field and the researcher's experience. Finally, the operational definition of the items was established ${ }^{(18)}$.

A three-point Likert scale was used to quantify these items, where zero meant "not uncomfortable at all", one "a 
little uncomfortable", and two "very uncomfortable", obtaining a score ranging from zero to 14 , in which 14 corresponded to the greatest intensity of discomfort reported. The three basic numerical scale axioms were observed: identity, order and additivity ${ }^{(18)}$. The three-point scale was chosen considering that the surgical patient would still be in the anesthetic recovery phase, and has to be able to understand and answer the questions with great accuracy, while other instruments and inventories that measure thirst are too extensive and complex to be used at that time.

The finished instrument was submitted to theoretical analysis in two distinct stages: face and content validation. Four nurses with Phds, four newly graduated nurses and eight patients (four with primary education and four with higher education levels) participated in the face validation. After applying the scale, the nursing researcher questioned each of the participants about the clarity and comprehension of the items.

Content validation of the scale was carried out by 11 specialists with perioperative nursing experience in the thirst theme or in instrument validation. Contact with specialists was carried out by email. They received four instruments: validation of thirst discomfort attributes; validation of the scale items; operational guide for validating the constitutive and operational definitions of the attributes; and an instrument for characterizing the specialists. The two-round Delphi technique was used for data collection.

The obtained data were organized and analyzed in an Excel 2007 spreadsheet. Content Validity Index (CVI) and the Interrater Agreement (IRA) were used for calculations. CVI demonstrates the proportion of specialists who judged the scale item as valid or not, applied to each attribute, to each scale item and to the instrument in its entirety. CVI was calculated for the scale items and attributes based on the ratio of the number of specialists who considered the scale item and the attribute (score of three or four) valid by the number of specialists. For the scale, CVI was based on the average values assigned to items and attributes. IRA was used to identify the extent to which experts were reliable in their responses. IRA was obtained from the ratio between the quantitative items of the scale that obtained values above $80 \%$ by the total number of scale items or attributes. Ideally, both indices should be greater than $80 \%{ }^{(20)}$.

A pilot test was performed with ten patients at the empirical procedures stage. This test guided problem identification for the items included in the scale and changes for clarity and understanding. The results are not included in the present report.

The last step corresponds to the analytical procedures, and consisted in verifying the scale's reliability. One of the research nurses and a resident nurse at the Post Anesthesia Care Unit, both with prior experience in perioperative nursing, conducted the inter-observer equivalence. The pair applied the scale simultaneously, but independently: only one of the nurses communicated with the patient, while the other watched and made notes. Data collection lasted 3 months, and in addition to the scale, the collection instrument included clinical and characterization data.
Pasquali's ${ }^{(18)}$ recommendations were adopted for sample calculation: ten subjects were required for each scale item, making up a sample of 70 patients. Patients from the immediate pre and post-surgical phase in an anesthetic recovery room were included. The criteria were: age between 18 and 65 years; reporting thirst; thirst score on the NVS greater than or equal to three; being aware, alert and oriented in time and space at the time of collection.

The data collected were organized in an Excel 2007 spreadsheet, and SAS 9.0 software was used for descriptive and inferential analysis. Two reliability verification techniques were selected: Cronbach's alpha and the inter-rater equivalence, calculating the weighted kappa coefficient. Both coefficients range from zero to one: the closer to one, the more accurate the measurement and the greater the instrument's reliability ${ }^{(17)}$.

The Research Ethics Committee of the study institution approved the study (CAAE: 02299412.6.0000.5231), under the guidelines of Resolution 466 of 2012 of the National Health Council.

\section{RESULTS}

Thirty representative attributes from the construct "thirst discomfort" were defined: bitter mouth, coarse mouth, irritated mouth, dry mouth, tiredness, brittle oral cavity, difficulty swallowing, headache, easy bleeding from oral cavity, sore throat, coarse throat, dry throat, bad taste in the mouth, hyposalivation, parched lips, cracked lips, thick tongue, dry tongue, bad breath, slightly dry eyes, dry eyes, loss of appetite, burning throat, burning in the stomach, thick saliva, drowsiness, dizziness, desire to drink water, desire to swallow and xerostomia (dry mouth).

The 30 attributes were reduced to the seven most representative of the construct: dry mouth, dry lips, thick tongue, thick saliva, dry throat, bad taste in the mouth and desire to drink water. Based on an operationalization of the attributes, we obtained seven corresponding items: my mouth is dry; my lips are dry; I feel my tongue is thick; my saliva is thick; my throat is itchy; I have a bad taste in my mouth; I feel like drinking water.

\section{FACE AND CONTENT VALIDATION}

Face validation demonstrated that Perioperative Thirst Discomfort Scale (Escala de Desconforto da Sede Perioperatória - EDESP) was easy to understand for all strata.

Of the 11 specialists invited for content validation, eight resided in Londrina; the others were from Maringá, Ribeirão Preto and São Paulo. Among them, one had a Post-doctorate in nursing, eight had Doctorate degrees and two had Master's degrees; four (45.4\%) had worked in the area for 25 to 30 years, $45.4 \%$ predominantly practiced their activities in undergraduate studies, and $81.8 \%$ worked in public institutions, $54.5 \%$ of which were in large public institutions.

The experts' judgment guided the following changes made in the scale: the item "feel that my tongue is thick" was changed to "my tongue is thick" in order to standardize; and the item "my throat is itchy" was changed to "my throat is dry", as the patients usually associated an itchy throat sensation with intubation in the anesthetic act. The criteria for 
qualifying the thirst discomfort assessment changed according to the experts' judgment and the scale pilot test with ten patients: instead of "not uncomfortable at all", "a little uncomfortable" and "very uncomfortable", zero was adopted as "not bothered", one for "slightly bothered" and two for "very bothered" (Chart 1), in order to provide patients with a better understanding and characterization of the scale items scoring system; in addition to spontaneous complaint, the periodicity of the evaluation also included questioning the patient about their thirst.

Chart 1 - Perioperative Thirst Discomfort Scale - Londrina, PR, Brazil, 2015.

\begin{tabular}{|c|c|c|c|}
\hline \multicolumn{4}{|c|}{ Perioperative Thirst Discomfort Scale - EDESP } \\
\hline Is the patient thirsty? & & \multicolumn{2}{|c|}{ () Yes () No } \\
\hline Spontaneous complaint? & & \multicolumn{2}{|c|}{ () Yes ( ) No } \\
\hline \multicolumn{4}{|l|}{ I'm bothered because: } \\
\hline & Not bothered & Slightly bothered & Very bothered \\
\hline My mouth is dry. & 0 & 1 & 2 \\
\hline My lips are dry. & 0 & 1 & 2 \\
\hline My tongue is thick. & 0 & 1 & 2 \\
\hline My saliva is thick. & 0 & 1 & 2 \\
\hline My throat is dry. & 0 & 1 & 2 \\
\hline I have a bad taste in my mouth. & 0 & 1 & 2 \\
\hline I want to drink water. & 0 & 1 & 2 \\
\hline Final score: & & & \\
\hline
\end{tabular}

Tables 1 and 2 show the results of the CVI and IRA data analysis. Agreement rates below $80 \%$ occurred only in the first round of content validation, while all attributes and items in the second round reached the levels established in this study. The item "my saliva is thick" had low indices in assessing the instrument for validation of the scale items, with CVI of $77 \%$ and IRA of $57 \%$.

Results obtained by the validation of attributes and the operating guide are presented in Table 2. In its judgment in the first instrument, IRA for the "thick tongue" attribute was $71 \%$ in the first round. Validation of the contents of the operating manual resulted in low IRA values for the attributes "dry lips" (0.50), "thick tongue" (0.50) and "dry throat" (0.75). Both indexes were below the ideal value for the attributes "thick saliva" and "bad taste".

Values below $80 \%$ on the indexes obtained in the content validation of the operating manual resulted from non-agreement of the experts regarding evaluation periodicity and qualification criteria of the scale items in the first evaluation round. Once the corrections were made, the scale presented 100\% CVI and IRA for all items in the second round.

Table 1 - Results of item content validation of the Perioperative Thirst Discomfort Scale - Londrina, Paraná. Brazil, 2015.

\begin{tabular}{|c|c|c|c|c|c|c|}
\hline Evaluated items & $\begin{array}{c}\text { CVI* } \\
1^{\text {st }} \text { round }\end{array}$ & $\begin{array}{c}\text { CVI** } \\
1^{\text {st }} \text { round }\end{array}$ & $\begin{array}{c}\text { IRA*** } \\
1^{\text {st }} \text { round }\end{array}$ & $\begin{array}{c}C V I^{*} \\
2^{\text {nd }} \text { round }\end{array}$ & $\begin{array}{c}C V I^{* *} \\
2^{\text {nd }} \text { round }\end{array}$ & $\begin{array}{c}\text { IRA*** } \\
2^{\text {nd }} \text { round }\end{array}$ \\
\hline My mouth is dry. & 0.97 & \multirow{6}{*}{0.91} & 1.00 & 0.98 & \multirow{6}{*}{0.98} & 1.00 \\
\hline My lips are dry. & 0.97 & & 1.00 & 0.98 & & 1.00 \\
\hline My tongue is thick. & 0.85 & & 0.86 & 0.98 & & 1.00 \\
\hline My saliva is thick. & 0.77 & & 0.57 & 0.98 & & 1.00 \\
\hline My throat is dry. & 0.84 & & 0.85 & 0.98 & & 1.00 \\
\hline I want to drink water. & 0.97 & & 1.00 & 0.98 & & 1.00 \\
\hline
\end{tabular}

*Content Validity Index - CVI of item of the scale; ** Content Validity Index - CVI of the full scale; ***:Interrater Agreement - IRA per item of the scale.

Table 2 - Results of the attributes' content validation of the Perioperative Thirst Discomfort Scale - Londrina, Paraná, Brazil, 2015.

\begin{tabular}{|c|c|c|c|c|c|c|c|c|c|c|c|c|}
\hline \multirow{2}{*}{ Attributes evaluated } & \multicolumn{2}{|c|}{ CVIa* } & \multicolumn{2}{|c|}{ CVIa** $^{* *}$} & \multicolumn{2}{|c|}{ IRAa $^{* * *}$} & \multicolumn{2}{|c|}{ CVIb* } & \multicolumn{2}{|c|}{$\mathrm{CVIb}^{* *}$} & \multicolumn{2}{|c|}{$\mathrm{IRAb}^{* * *}$} \\
\hline & $1^{\text {st }}$ round & $2^{\text {nd }}$ round & $1^{\text {st }}$ round & $2^{\text {nd }}$ round & $1^{\text {st }}$ rounc & $2^{\text {nd }}$ rounc & $1^{\text {st }}$ roun & dd $2^{\text {nd }}$ roun & $1^{\text {st }}$ roun & $2^{\text {nd }}$ roun & st roun & ${ }^{\text {nd }}$ round \\
\hline Dry mouth & 0.97 & 0.98 & & & 1.00 & 1.00 & 0.88 & 1.00 & & & 1.00 & 1.00 \\
\hline Dry lips & 0.91 & 0.98 & & & 1.00 & 1.00 & 0.81 & 1.00 & & & 0.50 & 1.00 \\
\hline Thick tongue & 0.83 & 0.98 & & & 0.71 & 1.00 & 0.83 & 1.00 & & & 0.50 & 1.00 \\
\hline Thick saliva & 0.91 & 0.98 & 0.91 & 0.98 & 1.00 & 1.00 & 0.79 & 1.00 & 0.83 & 1.00 & 0.50 & 1.00 \\
\hline Dry throat & 0.91 & 0.98 & & & 1.00 & 1.00 & 0.81 & 1.00 & & & 0.75 & 1.00 \\
\hline Bad taste & 0.91 & 0.98 & & & 1.00 & 1.00 & 0.79 & 1.00 & & & 0.50 & 1.00 \\
\hline Desire to drink water & 0.91 & 0.98 & & & 1.00 & 1.00 & 0.92 & 1.00 & & & 1.00 & 1.00 \\
\hline
\end{tabular}

*Content Validity Index - CVI of the attribute; ${ }^{* *}$ Content Validity Index - CVI of the full scale; ${ }^{* * *}$ Interrater Agreement - IRA per item of the scale. a - Attributes' Content Validation; $\mathbf{b}$ - Content Validation of the Operating Manual. 


\section{ReLIABILITY}

In the last step, a sample of 70 patients was determined to evaluate the reliability of the EDESP. The sample consisted of 36 men and 34 women, with a mean age of 38.3 years $(\mathrm{MD}=36.0$ and $\mathrm{SD}=14.4)$. The predominant educational level was secondary education $(61.4 \%) ; 32.9 \%$ had primary education and $5.7 \%$ higher. The main surgical specialties were Orthopedics (35.7\%) and Gynecology (27.1\%); cesarean section (15.7\%) was the surgical procedure with the highest incidence. No differences in fasting period of liquids or solids were found. $38.6 \%$ of the patients fasted for at least 12 hours; $55.7 \%$ between 12 and 24 hours, and $5.7 \%$ for a period of more than 24 hours. Surgeries lasted on average 1 hour and 59 minutes (MD=1 hour and 40 minutes and $\mathrm{SD}=1$ hour and 23 minutes).

Patients were predominantly submitted to spinal (58.6\%) and general (28.6\%) anesthesia, with average duration of 2 hours and 24 minutes $(\mathrm{MD}=2$ hours and $\mathrm{SD}=1$ hour and 30 minutes). Of the 70 patients, 23 (32.9\%) were intubated, and $37(52.9 \%)$ were ASA II, within the classification for anesthetic risk according to the general state.

Eight patients spontaneously reported thirst, and the mean NVS thirst score from zero to ten was 6.7 (MD=6 and $\mathrm{SD}=2.3$ ). Four patients received some anticholinergic medication, and $71 \%$ of them received opioid medication during surgery.

All items in the scale obtained a weighted kappa coefficient of 1 , with the exception of the item "I feel like drinking water", which was 0.97 . Internal consistency of the EDESP as verified by the Cronbach's alpha for the overall scale was 0.91 . The exclusion of any of the scale items did not increase the coefficient value, thus the seven previously defined items were maintained (Table 3).

Table 3 - Behavior of Cronbach's alpha with the exclusion of an item from the Perioperative Thirst Discomfort Scale - Londrina, Paraná, Brazil, 2015.

\begin{tabular}{lc}
\hline Item & Coefficient value \\
\hline My mouth is dry. & 0.90 \\
My lips are dry. & 0.89 \\
My tongue is thick. & 0.90 \\
My saliva is thick. & 0.90 \\
My throat is dry. & 0.89 \\
I have a bad taste in my mouth. & 0.90 \\
I want to drink water. & 0.90 \\
\hline
\end{tabular}

\section{DISCUSSION}

The results of this study showed that the evaluation of thirst does not only end in the intensity dimension, since self-reporting reveals the perception of specific and expressive discomforts composing peripheral attributes of thirst that cannot be ignored.

The 30 attributes identified for the discomfort of thirst in surgical patients and the EDESP are some of the main uncomfortable peripheral symptoms experienced in the perioperative phase, and many are often not even noticed by the nursing team. By starting with characterizing and operationalizing the most representative attributes of thirst discomfort, it was possible to elaborate, validate and verify the scale's reliability.

To date, no validated scale has been found in the literature to measure the discomfort of thirst in surgical patients, which gives importance to the usefulness and novelty of the result of this research. The scarcity of studies has made both the theoretical basis of the components of perioperative thirst and its discomfort difficult, as well as preparing directing the procedures for validation of assessment instruments.

The instruments found in the literature evaluated thirst in patients in the $\mathrm{ICU}^{(11)}$ or undergoing hemodialysis ${ }^{(12,14)}$, whose interest (in these cases) derives from the changes resulting from chronic kidney disease and the associated factors imposed on the organism ${ }^{(12,14)}$.

In the Thirst Distress Scale for hemodialysis patients, three dimensions were observed: discomfort, frequency and duration. At the end of ten interviews with patients, a literature review and theoretical definitions, 12 items were evaluated for the discomfort domain, three items for duration and 16 for frequency ${ }^{(12)}$.

An instrument was also developed to evaluate the incidence of thirst (Dialysis Thirst Inventory) in patients undergoing hemodialysis. This questionnaire has seven items inquiring about the period of the day when the urge to drink water was more incident, correlating the perception of thirst before, during and after the hemodialysis sessions ${ }^{(21)}$.

Despite several studies investigating a set of symptoms related to mucosal dryness invariably associated with thirst, no instruments evaluating them were found in the literature until the publication of the Xerostomia Inventory. This inventory consists of 11 items based on an extensive literature review and other studies evaluating xerostomia ${ }^{(14)}$.

Although validated and reliable, these scales are very extensive and include dimensions that are difficult to characterize and perceive for the patient in the immediate postoperative period, such as the duration of the symptom. They are inadequate to assess thirst discomfort in surgical patients who are exposed to factors they do not consider ${ }^{(22)}$.

The scoring system of a scale is an important factor that also interferes with measuring thirst. EDESP's qualification criteria were analyzed by specialists in the third instrument of content validation, consisting of a three-point Likert scale. A five-point Likert scale was used in previous instruments ${ }^{(12,14,21)}$. In the Thirst Discomfort Scale for hemodialysis patients, the respondent answered whether they agreed (score five) or not (score one) with the item under evaluation ${ }^{(12)}$; in the Xerostomia Inventory ${ }^{(14)}$ and Thirst Inventory ${ }^{(21)}$, "never" corresponds to score one, while "always" corresponds to score five, in relation to the periodicity of the evaluated aspect.

In the Xerostomia Inventory, an individual final score of 11 means that the "mouth is not dry", and 55 means that the "mouth is extremely dry" ${ }^{(14)}$, while in the Thirst Inventory a score of 7 corresponded to "not being thirsty", and 35 to being "very thirsty" (21). This inventory may not be practical to use with a surgical patient as it contains a large number of items with extensive punctuation, being difficult to understand for the patient in that period. 
One of the experts suggested that the EDESP evaluation criteria should be based on a four-point Likert scale. In aiming at patients' comprehension when recovering from a surgical procedure, we opted for the three-point Likert scale because its application is easier and more objective. A similar criterion was adopted in a randomized clinical trial to assess the intensity of thirst discomfort in ICU patients when using the Numerical Visual Scale of three points, although without explicitness of its attributes ${ }^{(11)}$. Thus, in the EDESP the final score ranges from zero to 14 , where 14 corresponds to the most intense discomfort of symptoms related to perioperative thirst.

In the content validation process with the judges, the attributes "thick tongue" and "my saliva is thick" did not obtain high indices of agreement in the first round. However, the researchers opted for not removing these items from the scale, supported by their clinical experience with patients with thirst. In the reliability evaluation, the relevance of these attributes was also verified within the scale, demonstrating that patients actually perceive a thick tongue and saliva as uncomfortable events; attributes also identified in other investigations with thirsty patients ${ }^{(1,7,13,22)}$.

Variability in individual perception regarding fasting, thirst, and gastric fullness has been investigated, since it is influenced by personal characteristics, as well as motivational and affective factors ${ }^{(22)}$. Thirst is also affected by physiological, environmental and health-disease process factors, being considered a multifactorial symptom ${ }^{(2,22)}$. EDESP seeks to evaluate these individual differences in thirst perception as it allows for discriminating the intensity of the discomfort caused by its different attributes, and which the scales that exclusively measure the intensity of thirst cannot differentiate.

EDESP proved to be reliable to be reproduced in studies with patients in the surgical phase by reaching almost perfect indexes in the second round of evaluation of the weighted kappa coefficient and Cronbach's alpha, since the production of random errors in repeated measurements was practically nil. An overall Cronbach's alpha of 0.91 revealed adequate internal consistency of the instrument, indicating that all items included in the scale actually represented the construct "thirst discomfort". Other studies obtained lower values $\left(0.78^{(12)}, 0.52^{(13)}\right)$ and a scale obtained similar alpha $\left(0.87^{(21)}\right)$. The index obtained by EDESP is within the ideal values for Cronbach's alpha, because if it were superior to the one found, it would indicate redundancy or duplication of the items, meaning that several items would be measuring exactly the same element of the thirst discomfort construct ${ }^{(23)}$.

This procedure is important to evaluate the adequacy of the items listed to compose an instrument. For example, in evaluating the reliability of a scale to determine thirst discomfort in hemodialysis patients ${ }^{(12)}$, the need to exclude all items related to measuring duration and frequency for effectively not measuring the proposed construct was identified.

Validation of EDESP followed three important steps: face validation, content and reliability index - the latter being a less used procedure in the validation of similar instruments ${ }^{(14)}$. Despite its methodological rigor, it is important to emphasize that the validity of an instrument should not only be confirmed by means of a single study ${ }^{(18)}$. The construct requires a pattern of consistent findings, involving different researchers for a significant period of time, and respecting a variety of relevant aspects ${ }^{(24)}$, which was also pointed out by the authors of the Xerostomia Inventory ${ }^{(14)}$.

Future studies in other realities may help to interpret the score obtained with the application of EDESP, and thus guide the proposition and planning of management strategies and thirst relief according to the degree of selfreported discomfort.

The concept of care directed to comfort defines it as a holistic and individualized practice, aiming toward the satisfaction of basic human needs and promoting relief from stressful factors in illness situations ${ }^{(6)}$. We believe that as a new instrument of care, EDESP can encourage the promotion of comfort based on the intentional identification of uncomfortable thirst symptoms that are so incident in surgical patients. Its use may be an initial step towards implementing measures for thirst relief and for improving the quality of perioperative care.

\section{CONCLUSION}

The present scale reached high indexes of validity and reliability, and with a large range of attributes as possibilities to evaluate thirst discomfort, the seven most representative attributes of the construct were identified: my mouth is dry, my lips are dry, my tongue is thick, my saliva is thick, my throat is dry, I have a bad taste in my mouth, and I want to drink water.

Face validation demonstrated that the scale is easy to understand and appropriate for perioperative use. Content validation by experts provided the optimum levels of content validity index (CVI) and reliability index or interrater agreement (IRA). Having a scale with a high index of reliability increases the safety for its use in clinical practice.

The use of EDESP should be reproduced in further studies with surgical patients and used in different realities with a greater number of patients and for prolonged periods. This may strengthen and corroborate the validity obtained by this research.

Objetivo: Elaborar e validar uma escala para avaliação do desconforto da sede perioperatória. Método: Pesquisa metodológica realizada em 2014 e 2015, no centro cirúrgico de um hospital público do norte do Paraná. A escala foi elaborada após revisão bibliográfica, seguida de validação aparente e de conteúdo e avaliação da fidedignidade através de sua consistência interna e da equivalência interobservadores. Resultados: Sete itens compuseram a escala: boca seca; lábios ressecados; língua grossa; saliva grossa; garganta seca; gosto ruim e 
vontade de beber água. $\mathrm{O}$ índice de validade de conteúdo para atributos e itens foi de 0,98 , e o índice de fidedignidade foi de 1 para os atributos e itens da escala. A consistência interna avaliada pelo alfa de Cronbach foi de 0,91 , e a equivalência interobservadores foi de 1, medida pelo coeficiente de kappa ponderado. Conclusão: A escala de desconforto da sede perioperatória demonstrou altos índices de validade de conteúdo e fidedignidade.

\section{DESCRITORES}

Sede; Escalas; Avaliação; Enfermagem Perioperatória; Estudos de Validação.

\section{RESUMEN}

Objetivo: Elaborar y validar una escala para evaluación de la incomodidad de la sed perioperatoria. Método: Investigación metodológica realizada en 2014 y 2015, en el quirófano de un hospital público del norte de Paraná. La escala fue elaborada tras revisión bibliográfica seguida de validación aparente y de contenido y evaluación de la credibilidad mediante su consistencia interna y la equivalencia entre los observadores. Resultados: Siete puntos compusieron la escala: boca seca; labios resecos; lengua gruesa; saliva gruesa; garganta seca; gusto malo y deseo de beber agua. El índice de validez de contenido para atributos indicadores fue de 0,98 y el índice de credibilidad fue de 1 para los atributos y puntos de la escala. La consistencia interna evaluada por el alfa de Cronbach fue de 0,91 y la equivalencia entre observadores fue de 1, medida por el coeficiente de kappa ponderado. Conclusión: La escala de incomodidad de la sed perioperatoria demostró altos índices de validez de contenido y credibilidad.

\section{DESCRIPTORES}

Sed; Escalas; Evaluación; Enfermería Perioperatoria; Estudios de Validación.

\section{REFERENCES}

1. Arai S, Stotts N, Puntillo K. Thirst in critically ill patients: from physiology to sensation. Am J Crit Care [Internet]. 2013 [cited 2015 Oct 2];22(4):328-36. Available from: http://www.ncbi.nlm.nih.gov/pmc/articles/PMC3718499/

2. Conchon MF, Nascimento LA, Fonseca LF, Aroni P. Perioperative thirst: an analysis from the perspective of the Symptom Management Theory. Rev Esc Enferm USP [Internet]. 2015 [cited 2015 Sept 24];49(1):120-8. Available from: http://www.scielo.br/pdf/reeusp/v49n1/00806234-reeusp-49-01-0122.pdf. DOI: http://dx.doi.org/10.1590/ S0080-623420150000100016

3. Millard-Stafford M, Wendland DM, O'Dea NK, Norman TL. Thirst and hydration status in everyday life. Nutr Rev [Internet]. 2012 [cited 2015 Oct 5];70 Suppl 2:S147-51. Available from: http://www.ncbi.nlm.nih.gov/pubmed/23121351

4. Tosun B, Yava A, Açikel C. Evaluating the effects of preoperative fasting and fluid limitation. Int J Nurs Pract. 2015;21(2):156-65.

5. Dessotte CAM, Rodrigues HF, Furuya RK, Rossi LA, Dantas RAS. Estressores percebidos por pacientes no pós-operatório imediato de cirurgia cardíaca. Rev Bras Enferm. 2016;69(4):741-50.

6. Kolcaba KY. Comfort theory and practice: a vision for holistic health care and research. New York: Springer, 2003.

7. Silva LCJR, Aroni P, Fonseca LF. Tenho sede! Vivência do paciente cirúrgico no período perioperatório. Rev SOBECC [Internet]. 2016 [citado 2016 out. 18];21(2):75-81. Disponível em: http://revista.sobecc.org.br/sobecc/article/view/21

8. Pavani MM, Fonseca LF, Conchon MF. Sede do paciente cirúrgico: Percepções da equipe de enfermagem nas unidades de internação. Rev Enferm UFPE [Internet]. 2016 [citado 2016 out. 20];10(9):3352-60. Disponível em: https://periodicos.ufpe.br/revistas/revistaenfermagem/ article/view/11416

9. Apóstolo JLA, Antunes M, Mendes A, Castro I. Conforto/Desconforto em doentes internados em Clínica Psiquiátrica. Rev Port Enferm Saúde Mental [Internet]. 2012 [citado em 23 out. 2015];(7):33-8. Disponível em: http://www.scielo.mec.pt/pdf/rpesm/n7/n7a06.pdf

10. Arai SR, Butzlaff A, Stotts NA, Puntillo KA. Quench the thirst: lessons from clinical thirst trials. Biol Res Nurs [Internet]. 2014 [cited 2015 nov. 19];16(4):456-66. Available from: https://www.ncbi.nlm.nih.gov/pmc/articles/PMC3989478/

11. Puntillo KA, Arai S, Cohen NH, Gropper MA, Neuhaus J, Paul SM, et al. Symptoms experienced by intensive care patients at high risk of dying. Crit Care Med [Internet]. 2010 [cited 2015 Oct 5];38(11):2155-60. Available from: https://www.ncbi.nlm.nih.gov/pmc/articles/ PMC3377582/

12. Welch JL. Development of the thirst distress scale. Nephrol Nurs J. 2002;29(4):337-42.

13. Yang YP, Wang CJ, Wang JJ. The initial development of a checklist for assessing thirst in patients with advanced dementia. J Nurs Res. 2016;24(3):224-31.

14. Thomson WM, Chalmers JM, Spencer AJ, Williams SM. The xerostomia inventory: a multi-item approach to measuring dry mouth. Community Dent Health. 1999; 16(1):12-7.

15. Aroni P, Nascimento LA, Fonseca LF. Avaliação de estratégias no manejo da sede na sala de recuperação pós-anestésica. Acta Paul Enferm [Internet]. 2012 [citado 2015 abr. 30];24(4):530-6. Disponível em: http://www.scielo.br/pdf/ape/v25n4/08.pdf

16. Medeiros RKS, Júnior MAF, Pinto DPSR, Vitor AF, Santos VEP, Barichello E. Modelo de validação de conteúdo de Pasquali nas pesquisas em enfermagem. Rev Enf Ref [Internet]. 2015 Fev. [citado em 19 nov. 2015];IV(4):127-35. Disponível em: http://www.scielo.mec.pt/pdf/ ref/vserlVn4/serlVn4a14.pdf

17. Polit DF, Beck CT, Hungler BP. Fundamentos de pesquisa em enfermagem: avaliação de evidências para a prática da enfermagem. $7^{a}$ ed. Porto Alegre: Artmed; 2011.

18. Pasquali L. Instrumentos psicológicos: manual prático de elaboração. Brasília: LabPAM; IBAPP; 1999.

19. Mokkink LB, Terwee CB, Patrick DL, Alonso J, Stratford PW, Knol DJ, et al. International consensus on taxonomy, terminology, and definitions of measurement properties: results of the Cosmin study. J Clin Epidemiol. 2010;63:737-45. 
20. Rubio DM, Berg-Weger M, Tebb SS, Lee ES, Rauch S. Objectifying content validity: conducting a content validity study in social work research. Soc Work Res. 2003; 27(2): 94-104.

21. Bots CP, Brand HS, Veerman ECI, Valentijn-Benz M, Amerongen BMV, Valentijn RM, et al. Interdialytic weight gain in patients on hemodialysis is associated with dry mouth and thirst. Kidney Int [Internet]. 2004 [cited 2015 Oct 20];66(4):1662-8. Available from: http:// www.sciencedirect.com/science/article/pii/S008525381550238X

22. Stevenson RJ, Mahmut M, Rooney K. Individual differences in the interoceptive states of hunger, fullness and thirst. Appetite. 2015;95:4457.

23. Streiner DL. Starting at the beginning: an introduction to coefficient alpha and internal consistency. J Pers Assess. 2003;80(1):99-103.

24. Pasquali L. Validade dos testes psicológicos: será possível reencontrar o caminho? Psic Teor e Pesq [Internet]. 2007 [citado 2015 out. 28];23(n.esp):99-107. Disponível em: http://www.scielo.br/pdf/ptp/v23nspe/18 